\title{
АКТУАЛІЗАЦІЯ ПРОБЛЕМИ ДИСКРИМІНАЦІї ЗА ВІКОМ: НАСЛІДКИ ПАНДЕМІЇ COVID-19
}

ГРЕНЬ Наталія Михайлівна - кандидат юридичних наук

В статье проводится анализ проблем дискриминации по возрасту в контексте пандемии COVID-19. Глобализачионнъе и глокализационнъге бакторьи, сочиально-экономическая диспропориия в обществе, политические трансбормации вызвали актуализацию проблем обеспечения равенства. Проблемъ дискриминации по возрасту касаются резких групп общества, однако особенно указанное характерно для лии пожилого возраста. Складъгвается стереотип, ито пожильие люди являются немощнълми, беспомощнъими и бремя для общества, которьй приводит к предупреждению и дискриминации.

В результате приоритетности мер борьбъ с пандемией в соответствии с нормативного регулирования пожилье люди, особенно в странах с низким и средним уровнем дохода сталкиваются с потерей бинансовой безопасности и имеют ограниченнъе возможности для получения дохода. Услуги медицинского характера при хронических заболеваниях бъли прерванъ из-за безопасных дистаниионнъих мероприятий, что для престарельхх наиболее необходимо.

Пожилье люди почувствовали проблемь пандемии угрожающими по следующим социальнъим составляющим: экономический кризис, угрозу бинансовой безопасности, неопределенную государственную политику, отсутствие разумного общественного приспособления, ненадлежащую работу общественнъхх служб и стигматизации. Государственная комплексная программа поддержки пожильих людей может стать надлежащей гаран- тией противодействия возрастной дискриминации.

Ключевъе слова: дискриминачия, дискриминация по возрасту, пожилье люди, пандемия COVID-19.

\section{Постановка проблеми}

Пандемічна криза несподівано захопила всю цивілізацію. Її вплив на суспільство є згубним. Першочергово вказане стосується економічної кризи. Однак прояви набагато масштабніші та прямо зачіпають конституційні права людини. Право на охорону здоров'я, право на пересування, на вибори та референдуми, право на освіту тощо - всі вони торкнулися питання проблеми обмеження і навіть дискримінації людини, спричинені загрозами Covid-19.

\section{Стан дослідження}

Питання прав людини, їх гарантій та проблем реалізації нині стали особливо актуальними. Видатні науковці у галузі теорії держави та права, конституційного права та галузевих наук неодноразово зверталися до цієї проблематики, серед яких Ю. Бисага, І. Жаровська, В. Ковальчук, Н. Оніщенко, П. Рабінович та інші. Проте проблемне поле дискримінації $\mathrm{e}$ дуже широким. Питання дискримінації за віковим критерієм у науковій думці сучасності розглядаються опосередковано, окрім того, пандемічна криза принесла додаткові виклики як для економічного, так і політико-правового життя. Тому по- 


\section{Теорія, історія держави і права, конституційне право}

требує додаткового аналізу задекларована проблематика.

Метої статті $\epsilon$ аналіз проблеми дискримінації за віком у контексті пандемії COVID-19.

\section{Виклад основних положень}

Проблема дискримінації нині є помітною як ніколи. Глобалізаційні та глокалізаційні чинники, соціально-економічна диспропорція у суспільстві, політичні трансформації спричинили актуалізацію проблем забезпечення рівності. Як вказує I. Жаровська, все ж таки державна влада залишається тією центральною інституцією, що захищає права та свободи громадян [див. 1].

Доволі часто сучасний соціум сприймає проблему дискримінації як другорядну. До речі, дискримінація за віком загалом є суспільною проблемою, проте i в українських реаліях не вважається аморальним порушенням, неприйнятною практикою. Такої ж думки й фахівці у сфері дискримінації, вони вказують, що «помітною причиною проблем у сфері реалізації органами державної влади та місцевого самоврядування своїх повноважень щодо запобігання та протидії дискримінації є їхній низький рівень обізнаності та розуміння положень як антидискримінаційного законодавства та принципів формування державної політики 3 питань недискримінації зокрема, так і визнання існування самої проблеми дискримінації загалом. Адже поширеною як у суспільстві, так і серед органів державної влади є думка про те, що проблема нерівності та дискримінації взагалі не притаманна Україні» [2, c.5].

Проблеми дискримінації за віком стосуються різких груп суспільства, проте особливо вказане характерне для осіб літнього віку. Складається стереотип, що люди похилого віку є немічними, безпорадними та тягар для суспільства, котрий призводить до упередження та дискримінації.
11 березня 2020 року Всесвітня організація охорони здоров'я оголосила COVID-19 пандемією.

Держави матимуть один із найгірших наслідків для здоров'я, що спричинені Covid-19, але природа глобальної економіки така, що мабуть, матимемо один із найгірших економічних результатів серед усіх років. Нині ми переходимо від очевидної кризи охорони здоров'я до прогнозованої економічної кризи, можна також міркувати про соціальні та політичні кризи на віддаленому горизонті.

入ітні люди як із захворюваністю, так i без хронічних хвороб були визначені вразливою групою, 3 високим ризиком важких наслідків та смертності. Зауважимо, що дискримінація не обмежується медичною проблематикою. Знову ж таки ВОО3 констатує, що пріоритети урядів, системи охорони здоров'я та глобальні установи не завжди зосереджуються на тих, кому загрожувала найбільша небезпека, отож на людях похилого віку.

Стурбованість посилюеться 3 приводу згубного впливу на людей похилого віку, спричиненого заходами пом'якшення наслідків передачі вірусу. Самотність вражає ^юдей різного віку і має істотний негативний вплив на фізичний стан людини, когнітивне здоров'я, збільшуючи ризик тривоги, депресії та самогубств.

Проблеми також можна відобразити через категорії стигматизації. Соціальна стигма в контексті здоров'я - це негативна зв'язок між людиною або групою людей, які поділяють певні особливості, і конкретним захворюванням. Під час спалаху це може означати, що людей позначають ярликами, стереотипами, дискримінацією, окремим ставленням. Аюди, які не страждають хворобою, але поділяють інші характеристики 3 цією групою, також можуть страждати від стигми. Нинішній спалах COVID-19 спровокував соціальну стигму та дискримінаційну поведінку щодо людей певного віку, а також усіх, хто, як вважається, контактував з вірусом.

COVID-19 суттево вплинув на життя всіх людей на планеті Земля, але не пропорційно вплинув на життя та засоби іс- 
нування літніх людей. Дискримінація погіршила глобальні кризові явища і перешкоджає необхідним рішенням. Пандемія непропорційно вплинула на людей похилого віку у всьому світі, завдавши нищівних ударів по їх фізичному здоров'ю, психічному здоров'ю та засобах до існування. Особливо страждають люди в закладах тривалого догляду. Проблеми в структурах довгострокового догляду існували до цієї глобальної пандемії, однак нині вони актуалізувалися.

Стереотипи, упередження та дискримінація за віком посилюють наявну нерівність та перешкоджають ефективним протидіям. Припущення, що всі люди похилого віку є немічними або залежними, є не тільки неточним, але й шкідливим [3].

Covid-19 виявив, використав та підкреслив глибокі соціально-економічні та расові диспропорції. Він вразив усіх, проте це велике порушення було особливо руйнівним для людей похилого віку. До того ж науковці виокремлюють групову дискримінацію комплексного характеру, які зумовлені не тільки віком, але й у поєднанні зі статтю, расовими чинниками тощо. У моніторинговому звіті Світового економічного форуму, що проводився у жовтні 2020, вказано, що «люди похилого віку, що належать до певних груп расових та етнічних меншин, особливо в зоні ризику внаслідок неадресованої системної нерівності» [4].

У результаті пріоритетності заходів боротьби з пандемією відповідно до нормативного регулювання літні люди, особливо в країнах з низьким та середнім рівнем доходу стикаються 3 втратою фінансової безпеки та мають обмежені можливості для отримання доходу. Послуги медичного характеру при хронічних захворюваннях були перервані через безпечні дистанційні заходи, що для літніх людей найбільш потрібні.

Зробимо ще один акцент. Громада, територіальні органи - це та суттєва ланка, котра може забезпечити належну соціально-побутову та правову сферу осіб літнього віку. Децентралізація - це реформа не тільки політико-владного характеру, а по- кликана усунути проблеми реалізації належного соціально-правового статусу громадян. Як правильно зазначено у Концепції реформування місцевого самоврядування та територіальної організації влади в Україні, схвалена розпорядженням Кабінету Міністрів України від 1 квітня 2014 р. № 333-р «система місцевого самоврядування на сьогодні не задовольняє потреб суспільства. Функціонування органів місцевого самоврядування у більшості територіальних громад не забезпечує створення та підтримку сприятливого життєвого середовища, необхідного для всебічного розвитку людини, іï самореалізації, захисту іiі прав, надання населенню органами місцевого самоврядування, утвореними ними установами та організаціями високоякісних і доступних адміністративних, соціальних та інших послуг на відповідних територіях». Вказану проблему найбільше помічають особи старшої вікової групи. Пандемія ще раз продемонструвала потребу оновлення життєво-побутової сфери відповідно до технічних та інформаційних можливостей.

Окрім того, саме пандемія чітко довела, що сімейне опікунство нині $є$ найкращим засобом людської комунікації. Така форма сімейної взаємодії в Україні вже давно перевірена часом, вона притаманна нашим ментальним та історичним традиціям. Тому зміна сімейного співжиття за формою активізації інших форм, наприклад, будинків для людей літнього віку - це можливий, проте не пріоритетний шлях розвитку сімейної політики України.

Добре спроєктований район проживання і громадські простори можуть надалі сприяти здоров'ю та добробут літніх людей. Вагомим тут є критерій містобудування. Згідно із Законом України «Про основи містобудування» «(містобудівна діяльність) - це цілеспрямована діяльність державних органів, органів місцевого самоврядування, підприємств, установ, організацій, громадян, об'єднань громадян по створенню та підтриманню повноцінного життєвого середовища, яка включає прогнозування розвитку населених пунк- 


\section{Теорія, історія держави і права, конституційне право}

тів і територій, планування, забудову та інше використання територій, проєктування, будівництво об'єктів містобудування, спорудження інших об'єктів, реконструкцію історичних населених пунктів при збереженні традиційного характеру середовища, реставрацію та реабілітацію об'єктів культурної спадщини, створення інженерної та транспортної інфраструктури» [5]. Нині вагомо не просто говорити про розвиток містобудування, а про створення цілісної системи «розумних міст».

Новітні форми проєктування громадського простору передбачають інтеграцію інформаційних та комунікаційних технологій, 3 метою ефективного управління інфраструктурою міста (транспорт, безпека, медицина, комунальна система). Їх основною ціллю 6 покращення якісних показників життя мешканців, для цього використовують розвиток технологій для задоволення потреб городян. Для більшості людей старшого віку, навіть у розвинених країнах доступні пристосування та відкриті простори - все ще далека перспектива.

I наостанок. Майже $70 \%$ світового населення живе в країнах з низьким рівнем доходу. Особи літнього віку не завжди можуть отримувати належне пенсійне забезпечення або доволі часто не отримують його взагалі, тому зобов’язані працювати навіть при небезпеці пандемії. Вони перебувають у вищій категорії ризику зараження (наприклад, через контакт із клієнтами та колегами, використання системи громадського транспорту).

\section{Висновок}

Пандемія COVID-19 спровокувала ріст дискримінаційних чинників, серед яких i дискримінацію за віком. Аітні люди відчули проблеми пандемії загрозливо через наступні соціальні складові: економічну кризу, загрозу фінансової безпеки, невизначену державну політику, відсутність розумного громадського пристосування, неналежну роботу громадських служб та стигматизацію. Державна комплексна програма підтримки людей літнього віку може стати належною гарантією протидії вікової дискримінації.

\section{Лiтература}

1. Жаровська I. М. Державна влада: правові категорії : монографія. Аьвів: Вид-во Аьвів. комерц. акад., 2012. 195 с.

2. Пономарьов С.Ю., Федорович І.Ю. Запобігання та протидія дискримінації в Україні: Посібник для працівників органів державної влади та місцевого самоврядування. К.: Міжнародна організація 3 міграції, Представництво в Україні, 2014. $74 \mathrm{c}$.

3. ONS, Coronavirus (Covid-19) Related Deaths by Occupation, England and Wales: Deaths Registered up to and Including 20 April 2020, 11 May 2020.

4. COVID and Longer Lives: Combating ageism and creating solutions. Community Paper. October 2020. C. 25

5. Про основи містобудування: закон України від 16.11.1992 № 2780-XII // Biдомості Верховної Ради України. 1992. № 52. ст.683.

\section{UPDATING THE PROBLEM OF AGE DISCRIMINATION: CONSEQUENGES OF THE COVID-19 PANDEMIC}

The article analyzes the problems of age discrimination in the context of the COVID-19 pandemic. Globalization and glocalization factors, socio-economic disparity in society, political transformations have led to the actualization of equality issues. The problems of age discrimination concern a large group of society, but this is especially true for the elderly. There is a stereotype that the elderly are weak, helpless and a burden on society that leads to prejudice and discrimination.

As a result of the priority of pandemic measures in accordance with regulations, the elderly, especially in low- and middleincome countries, face a loss of financial security and have limited opportunities to earn an income. Medical services for chronic diseases have been interrupted due to the safe remote measures that are most needed for the elderly. 


\begin{tabular}{|c|}
\hline 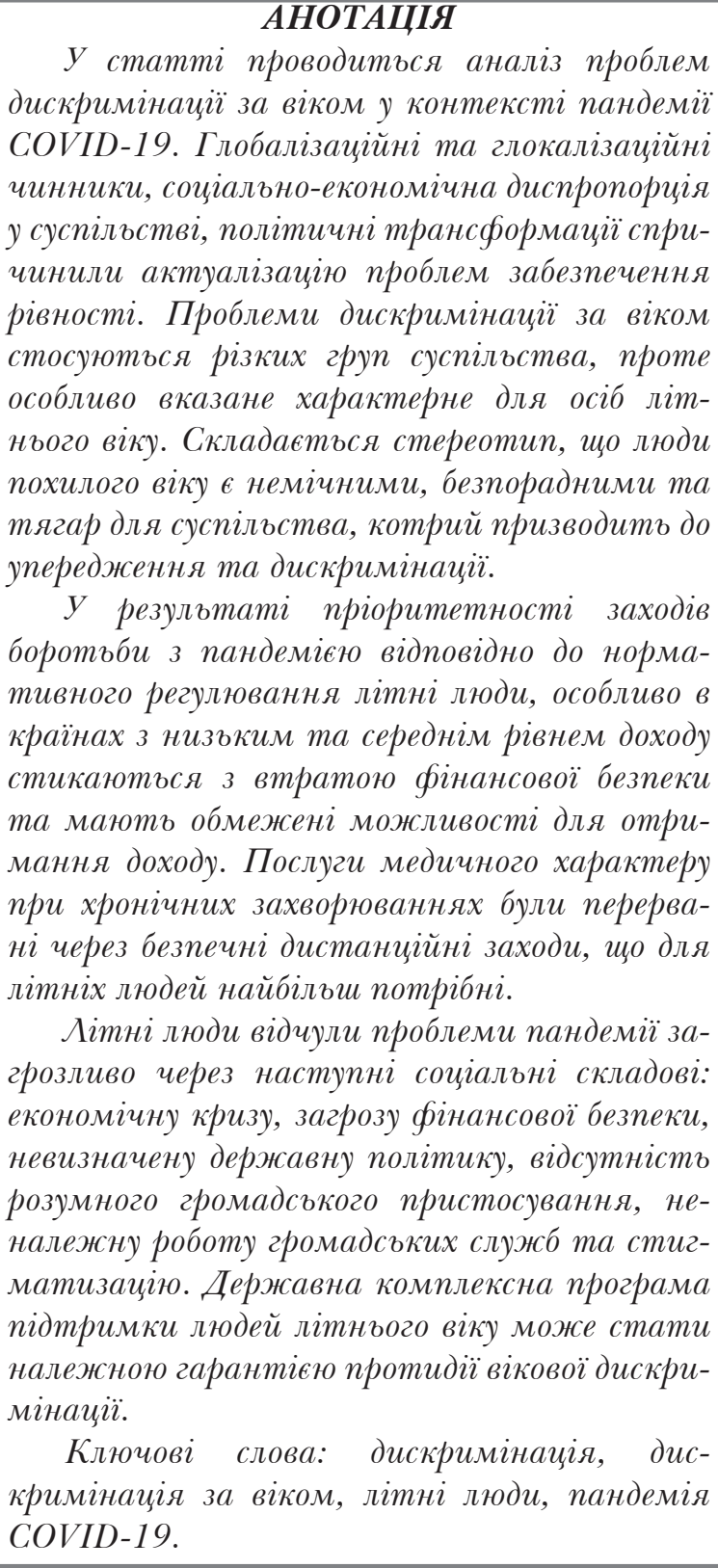 \\
\hline
\end{tabular}

Elderly people have experienced the problems of the pandemic threateningly due to the following social components: economic crisis, threat to financial security, uncertain public policy, lack of reasonable public accommodation, improper work of public services and stigma. A comprehensive state program to support the elderly can be an appropriate guarantee against age discrimination.

Key words: discrimination, age discrimination, elderly people, COVID-19 pandemic. 